\title{
Application of Institutional Engineering Economics for Plateau Vegetable Farmers for Tourism Market Access
}

\author{
Nyoman Parining Made Antara Dwi Putra Darmawan Ni Wayan Sri Astiti \\ Doctoral Program in Agricultural Science, Faculty of Agriculture, Udayana University
}

\begin{abstract}
The purpose of this study is to model the strengthening of plateau vegetable farmers groups in Bali. One way is to transform group institutions into dynamic, empowered and business-oriented institutions. The study began by interviewing plateau farmer groups in Pancasari Village, Sukasada District of Buleleng and Candikuning Village, Baturiti Regency, Buleleng Regency, and also interviewing hotels as representatives of institutional consumers in the tourism industry. To get conditions that are more comprehensive, in-depth interviews were conducted with key informants. Next, a meeting of experts was followed to get a more comprehensive picture to be able to produce a model of strengthening the group of plateau vegetable farmers to meet the tourism market in Bali. ISM analysis is used in this research to get the driving force and dependence of the elements and sublements that build the modeling.Empirical facts, especially the difficulty of farmer groups to access institutional markets, production projections are not in accordance with institutional market needs, in groups there are no functional organizational structures (production divisions, processing divisions, and marketing divisions), and institutional supply chains that have not been optimally utilized as a reference in strengthening the farmer group expert meeting. As a result of the expert meeting, it was formulated that the establishment of a Socio-agro-enterprise institution would embrace inclusive all groups of vegetable farmers in the plateaus. The Village-owned business entity form is the right choice for new institutions. Village-owned business entity plateau vegetable farmers are the main players in the vegetable business operating in Bali. In running its business, Village-owned business entity carries out a vertical integration strategy that has a vegetable plantation and a packing place. However, to meet institutional consumer market demands beyond existing capacities, it is necessary to implement a vertical coordination strategy with Village-owned business entity partners in the open market, for the procurement of ready-to-sell vegetables or other groups of vegetable growers.Strengthening a group of vegetables oriented to the development of organizational management and strategic marketing and supported by government regulations in fostering market infrastructure ensures an increase in the performance of the vegetable supply chain and tourism market access. Implementation of an effective model of strengthening the plateau vegetable farmers group requires multisectoral synergy to increase innovation support and strengthening programs.
\end{abstract}

Keywords: strengthening model of farmer groups, plateau vegetables, institutional consumers

DOI: $10.7176 / \mathrm{JESD} / 11-10-03$

Publication date:May $31^{\text {st }} 2020$

\section{I.Introduction}

In Asia, smallholder agriculture produces around $20 \%$ of GDP and $43 \%$ absorbs labor. Eastern Europe and Latin America both produce about $8 \%$ of GDP and $22 \%$ of employment (World Bank, 2007). Although smallholder farmers have an important role in food security in developing countries, farmers continue to live in poverty in rural areas. In Indonesia, most small farmers do not have direct access to organizational markets. Farmers market agricultural products through local collectors. In the case of horticultural products, small farmers sell $65 \%$ of their products to local collectors. Only about $10 \%$ of farmers are connected and have arrangements with suppliers of agricultural products to supermarkets (Natawidjaja, 2005). The rest, farmers sell to places such as traditional markets and stalls around the location of residence. About $75 \%$ of the vegetable farmers in the vegetable center in Bali, namely the Bedugul, Baturiti and Kintamani areas are smallholder farmers, only $5 \%$ sell vegetables directly to hotels, $85 \%$ sell vegetables to traders, and the remaining $35 \%$ sell to traditional markets (Parining, 1999). The increasing number of hotels in Bali, which is followed by an increasing number of tourist visits, requires an increased supply of food, especially vegetables, for hotels. Adequate to improve service. But in reality, hotels which include organizational consumers (organizational consumers) have certain criteria in buying food products such as vegetables. Individual farmers with various limitations find it difficult to market their vegetable products directly to hotels in the tourism area of Bali. To improve the competitiveness and bargaining power of products, farmers form groups forming an institution commonly known as farmer groups.

Plateau vegetables in Bali are in a relatively limited area, namely in the villages of Pancasari and Candikuning. To be able to access to institutional consumers and sustainable relationships, farmers need to engage. There are many definitions of custumer engagement, including those conveyed by Forrester Consulting (2008) that customer attachment creates purchasing decisions, interactions, and participation on an ongoing basis. Sustainability means a long-term and intimate relationship between producers and consumers. Given the meaning of engagement, it will benefit producers and consumers. A business that is able to grow sustainably is a business that is able to create 
repeat purchases from one or a group of customers so as to create customer attachment or customer engagement. Farmer institutionalization is a central point in driving the agribusiness system in rural areas. However, because of their lack of insight and knowledge on the issues of production management and marketing networks, the institutional function of farmers is not optimal to respond to market demand. Although there are many farmer groups as a container for farmer organizations, they have not yet played an optimal role. One of the reasons is that some farmer groups group themselves which only aims to capture government assistance and do not preserve the interests of group members in marketing their produce, so that farmers in marketing their agricultural products run individually. The problem is the model of strengthening the group of plateau vegetable farmers oriented to strategic organization and marketing and supported by proposed government regulations to guarantee increased access to the tourism market.

\section{Literature Review}

\section{Socio-Agro-Enterprise Oriented Farmer Institution to Meet the Tourism Sector Market}

Legally strengthening farmers' economic institutions is strongly supported by the central and regional governments. This is reflected in the passing of laws and government regulations to legally guarantee the existence of farmer institutions, among others through Law Number 19 of 2013 concerning Farmer Protection and Empowerment, it is stated that the government and regional government in accordance with their authority are obliged to encourage and facilitate the formation of farmer institutions and Farmer Economic Institutions (KEP); Law Number 32/2004 concerning Regional Government explained that villages could establish Village-owned business entity to facilitate the economic activities of rural communities; 2) Government Regulation (PP) Number: 72 of 2005 concerning Villages, states that Village-owned business entity are legal entities. However, in its journey Villageowned business entity does not have a foundation to become a legal entity, it is the business unit that allows for legal entity; 3) Regulation of the Minister of Home Affairs (Permendagri) Number: 39 of 2010, the Village Owned Enterprises (Village-owned business entity) was formed in several villages in several districts; and 4) Law No. 6 of 2014 concerning Villages provides a new spirit for villages to empower themselves by giving birth to a spirit of village development, meaning that the village is placed as a milestone in the beginning of national development. So that the strengthening of the village can not be separated from the strength of the village in exploring the potential of local wisdom and the spirit of mutual cooperation of its citizens (Kolopaking et. Al., 2014). Villageowned business entity belongs to the village which is engaged in the economy and has a social nature because of its benefits to the village community, including farmers.

The process of economic development of farmers requires optimal ability in agricultural activities. Capabilities related to empowerment include: 1). Creating a conducive climate so that farmers are able to form and grow their groups in a participatory manner (from, by and for farmers); 2) Growing the creativity and initiative of farmer farmers to take advantage of every business opportunity, information and access to capital available; 3 ) Help expedite the process of identifying needs and problems as well as formulating plans and solving problems encountered in his farm; 4) Increase the ability to analyze market potential and business opportunities and analyze the potential of the region and the resources owned to develop commodities developed / endeavored to provide greater business profits; 5) Increase the ability to be able to manage farming in a commercial, sustainable and environmentally friendly manner; 6) Enhancing the ability to analyze the business potential of each member to become a business unit that guarantees market demand in terms of quantity, quality and continuity; 7) Develop the ability to create specific local technologies; 8) Encourage and advocate for farmers to be willing and able to carry out savings and loan activities to facilitate the development of venture capital (Tanziha, 2011).

Tourism Market

In 2013-2017 foreign tourists coming directly to Bali increased by 42\%. Domestic tourists (wisdom) are also a very important market for Bali because of their rapid growth. In tourist destinations, tourists need to eat and drink both fresh and processed. Therefore institutional market (tourism) is a potential market for local agricultural products including upland vegetables.

Institutional consumers are limited in number when compared to end consumers, but have a very important meaning for marketers because they buy goods in large quantities (Evan and Berman, 1997). The demand for quality, continuity and the ngebon system is an obstacle for farmers to sell their products. Farmer institutional engineering needs to be done to access institutional markets, especially preparing reliable human resources in marketing, technical and processing and services for institutional markets (Natawidjaja, 2005).

Interpretive Structural Modeling (ISM)

Many theories have been developed for strategic planning where qualitative and normative information dominate the policy input (Warfield and Cardenas, 1994; Warfield, 2006). The one of them are "Interpretive Strutural Modeling" which is descriptive modeling technology that one of structuring tools for a direct relationship (Eriyatno, 2003; Shahabadkar et al., 2012; Darmawan, 2017). The program can be divide by nine elements: 1) affected peoples, 2) program needs, 3) main problems, 4) possible change, 5) program goals, 6) benchmark to judges every goals, 7) activity required for action plans, 8) involved institutions in action programs, and 9) certain elements 
(Saxena et al., 1990; Saxena et al., 1992).

\section{III.Methods}

Types and Data Resources

The type of data collected in this study is qualitative data such as market access, supply chain, local vegetable attributes according to farmers and hotels. Data sources are primary sources that produce primary data obtained from original sources, namely the Head of Farmer Group respondents and experts (expert). Whereas secondary sources that produce secondary data are obtained and reported in advance by other people or institutions apart from research.

Data Collection Methods

The procedures for collecting research data are described as follows: (1) Problem identification is obtained from surveys of farmer groups, institutional consumers (hotels) and key informants (chairpersons, secretaries and group treasurers and local collector agents); (2) Data generated in surveys and in-depth interviews are used as preliminary information submitted in expert meetings to create a planning program with ISM; (3) The ISM results in the form of the main elements driving the synthesized system to produce multi-criteria to form a model for strengthening the plateau farmer groups.

Respondent and Research Sample

The study population consisted of all farmer groups in the study area and all star hotels in Bali. The population of the vegetable farmer group is 14 groups spread in Candikuning Village with 10 vegetable farmer groups and Pancasari Village with four vegetable farmer groups with a total of 435 members. Following the Slovin method, the number of research samples for group respondents with a level of accuracy of $10 \%$ was 81 people. Sampling for each farmer group was determined by purposive sampling and random sampling. Determination of the sample by purposive sampling with consideration of members of the farmer group as chairperson, secretary and treasurer of the group so that the total sample of 42 people. The remaining 39 respondents were determined by random sampling from members of farmer groups. The hotel population is all star hotels in Bali in 2013 assuming all star hotels have restaurants that require vegetables as food ingredients. While there are non-star hotels that have restaurants and some who do not have restaurants. The sampling method is by the Slovin method, but previously the population in the strata was based on hotel class classes into five hotel classes, namely one, two, three, four, and five stars. Determination of the sample for each hotel stratum is determined by random sampling. In the table can be seen the total number of hotel samples as many as 69 hotels.

In addition to samples from farmers and hotels, key informants are also needed to conduct in-depth interviews. Key informants are the chairperson / secretary / treasurer of the farmer group and local collector agent. The determination of expert meeting participants / FGDs was carried out intentionally (purposive), namely representatives of elements of hotel associations, suppliers, vegetable farmers associations, central and regional governments, Non-Governmental Organizations, local collectors, transportation entrepreneurs, microfinance institutions and cooperatives providing production facilities.

Data Analyze Methods

Various steps in ISM modeling: identifying elements relevant to the problem under consideration. This can be done by surveying techniques or group problem solving, establishing contextual relationships between elements regarding pairs of elements to be examined, developing the Structural Self-Interaction Matrix (SSIM) of the elements. This matrix shows pairwise relationships between system elements. This matrix needs to be examined for its transitivity, develops the Reachability Matrix of SSIM, partition the Reachability Matrix to a different level, converts the Reachability Matrix to conical form, draws digraph based on relationships in the Reachability Matrix and removes transitive links, converts the generated digraph into an ISM based model by replacing node elements with statements, model reviews to check conceptual inconsistencies and make necessary modifications.

The ISM methodology proposes the use of expert opinions based on various management techniques, such as brain storming and nominal group techniques in developing contextual relationships between variables (Ravi et al., 2005; Barve et al., 2007; Hasan et al., 2007) . For this purpose, experts, both industrialists and academics must consult to identify the nature of contextual relationships between factors. Industryists and academics must be well versed with the issues considered. To analyze factors, contextual relationship leads to or influences must be chosen. This means that one factor influences another. On this basis, contextual relationships were developed between the factors identified. The following four symbols are used to indicate the direction of the relationship between two factors ( $i$ and $j$ ): (a) $V$ for the relationship from factor $i$ to factor $j$ (factor $i$ will affect factor $j$ ); (b) A for the relationship of factor $\mathrm{j}$ to factor $\mathrm{i}$ (factor $\mathrm{i}$ will be influenced by factor $\mathrm{j}$ ); (c) X for a two-way relationship (factors $\mathrm{i}$ and $\mathrm{j}$ will affect each other); (d) $\mathrm{O}$ for no relationship between factors (factors $\mathrm{i}$ and $\mathrm{j}$ are not related).

\section{IV.Result and Discussion}

Empirical Facts as an Expert Meeting Reference

Empirical facts such as market access, supply chain, local vegetable attributes according to farmers and local 
vegetable attributes according to consumer institutions (hotels) are then used as a reference in expert meetings for strengthening the group of plateau vegetable farmers in the context of supply chain management, especially the difficulty of farmer groups accessing institutional markets, the production projection is not in accordance with the institutional market needs, within the group there is no functional organizational structure (production division, processing division and distribution division), and the institutional plateau supply chain is not optimal.

Planning for Strengthening Vegetable Farmers Group Programs with ISM

The ISM methodology itself has two parts, namely the classification of sub-elements and the development of the hierarchy (Table 1 columns 3 and 4). The various sub-elements in an element are then described in the powerdependent matrix driver (Godet, 1985). For the purpose of classifying sub elements, the power-dependent matrix driver is divided into the following four sectors (known as ADLI sectors) (see Table 1 column 3).

a. Sector A: Autonomous. Weak driver and weak dependent variable (point near origin); groups called autonomous variables. This variable is a factor that is relatively disconnected from the system (disconnected from the system); this variable only has a few links, although this link can be very powerful.

b. Sector D: Dependent. Driver variables are weak and very dependent. This variable is mainly the dependent variable.

c. Sector L: Linkage. Driver variables are powerful and very dependent. This variable must be studied more carefully. This linkage variable is unstable. Every action on these variables will have an impact on other variables and have a feedback effect on the variable itself to strengthen or support the initial pulse.

d. Sector I: Independent. The driver variables are strong and the dependent is weak. This variable is the rest of the system and is called an independent variable.

Program planning is essential in realizing a socio-enterprise institution and for the purpose of analysis is summarized into five elements, namely program needs, program constraints, possible changes, program objectives, and the institutions involved (Table 1 column 1, lines 1-3). The five elements are further divided into sub elements. The number of sub-elements in each element has been carefully considered. The program planning for strengthening the plateau vegetable farmers group has considered 6 program needs, 10 constraints, 12 possible changes, 8 objectives, and 9 agencies. So there are 45 sub-elements in the system (Table 1 column 2). For the purpose of Interpretive Structural Modeling, contextual relations for each of these elements are presented as in Table 2.

In order for contextual relations to be observed, SSIM was developed using the symbols $\mathrm{V}, \mathrm{A}, \mathrm{X}, \mathrm{O}$ and obtained SSIM for each element. Then obtained Reachability Matrices for each element of each SSIM by replacing the values of $\mathrm{V}, \mathrm{A}, \mathrm{X}, \mathrm{O}$ with numbers 1 or 0 .

Table 2. Contextual Relationships of Elements

\begin{tabular}{|l|l|}
\hline \multicolumn{1}{|c|}{ Elements } & \multicolumn{1}{c|}{ Contextual Relationships } \\
\hline 1. Program requirements & One need will have an effect on other needs in the program. \\
\hline 2. Program constraints & One obstacle contributes to other obstacles in the program. \\
\hline 3. Possible changes & One change will make changes to other elements in the program. \\
\hline 4. Program objectives & One goal helps other objectives in the program. \\
\hline 5. Related institutions & One institution assists other institutions in the program. \\
\hline
\end{tabular}


Table 1. Classification and Hierarchy, and the Main Sub Elements of the System Mover

\begin{tabular}{|c|c|c|c|c|c|}
\hline Elements & $\begin{array}{l}\text { Sub element } \\
\text { (E) }\end{array}$ & $\begin{array}{l}\text { Power-Dependence Driver Matrix for sub-classification } \\
\text { classification }\end{array}$ & \multicolumn{2}{|c|}{ Digraph for hierarchical development } & \multirow{2}{*}{\begin{tabular}{|c|}
$\begin{array}{l}\text { The main sub } \\
\text { element driving the } \\
\text { system }\end{array}$ \\
(5) \\
\end{tabular}} \\
\hline (1) & (2) & (3) & & (4) & \\
\hline $\begin{array}{l}\text { 1. Program } \\
\text { Requirements }\end{array}$ & $\begin{array}{ll}\text { 1. } & \text { Development of business } \\
\text { actors } & \text { Capital } \\
\text { 3. } & \text { Market Access } \\
\text { 4. Socio-enterprise institutional } \\
\text { d. Development } \\
\text { 5. Development of } \\
\begin{array}{l}\text { environmentally friendly } \\
\text { production management } \\
\text { 6. Engagement between farmers } \\
\text { and tourism industry / } \\
\text { consumers }\end{array}\end{array}$ & 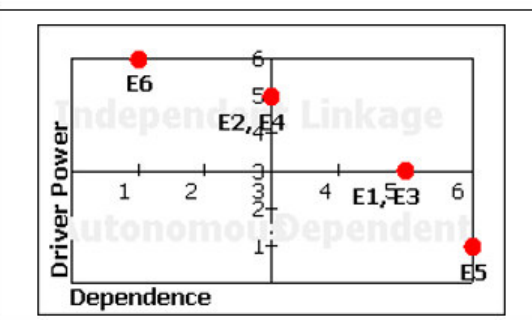 & $\begin{array}{l}\text { Level 1: } \\
\text { Level 2: } \\
\text { Level 3: } \\
\text { Level 4: }\end{array}$ & $\begin{array}{r}\frac{E 5}{4} \\
\underline{E 1, E 3} \\
\mathbb{E} \\
E 2, E 4 \\
\mathbb{4} \\
\underline{E 6}\end{array}$ & $\begin{array}{l}\text { Engagement } \\
\text { between farmers } \\
\text { and the tourism } \\
\text { industry / } \\
\text { consumers } \\
\text { Socio- } \\
\text { enterprise } \\
\text { institutional } \\
\text { development } \\
\text { Capital }\end{array}$ \\
\hline $\begin{array}{l}\text { 2. Program } \\
\text { constraints }\end{array}$ & 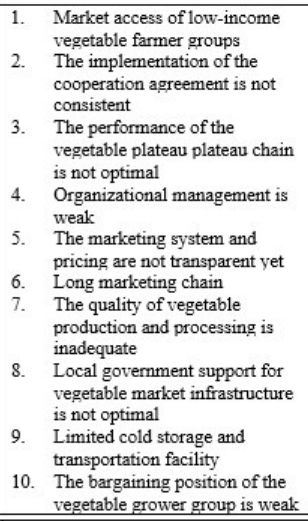 & 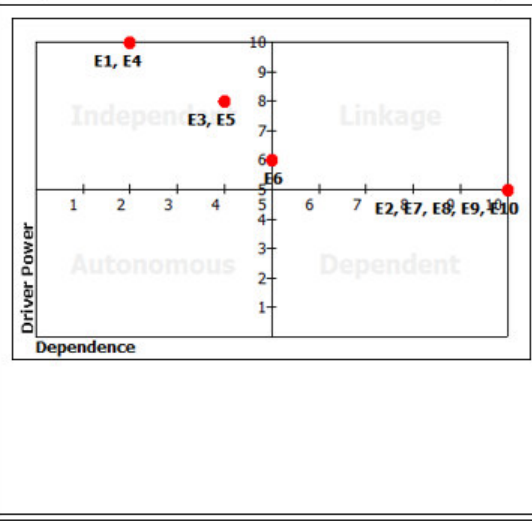 & $\begin{array}{l}\text { Level 1: } \\
\text { Level 2: } \\
\text { Level 3: } \\
\text { Level 4: }\end{array}$ & 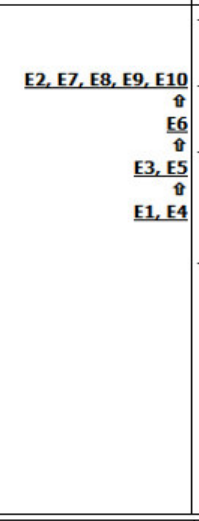 & $\begin{array}{l}\text { Market access of } \\
\text { vegetable grower } \\
\text { grouss is low } \\
\text { Organizational } \\
\text { managagenent is } \\
\text { weak } \\
\text { The performance } \\
\text { of the vegetable } \\
\text { plateau plateau } \\
\text { chain is not } \\
\text { optimal } \\
\text { The marketing } \\
\text { system and prices } \\
\text { are not } \\
\text { transparent yet }\end{array}$ \\
\hline $\begin{array}{ll}\text { 3. } & \text { Changes } \\
\text { Possible }\end{array}$ & 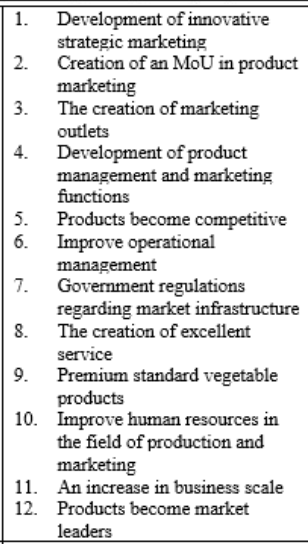 & 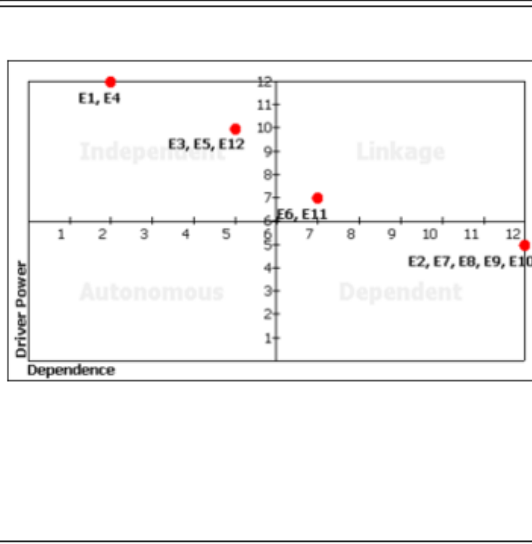 & $\begin{array}{l}\text { Level 1: } \\
\text { Level 2: } \\
\text { Level 3: } \\
\text { Level 4: }\end{array}$ & 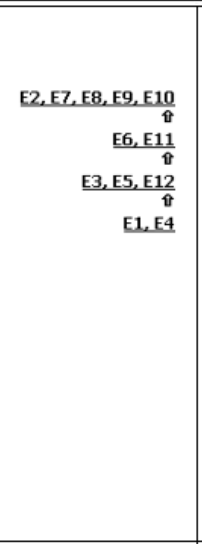 & $\begin{array}{ll}- & \text { Development of } \\
\text { inovative } \\
\text { strategic } \\
\text { marketing } \\
\text { Development of } \\
\text { product } \\
\text { management and } \\
\text { marketing } \\
\text { functions } \\
- \text { The creation of } \\
\text { marketing outlet } \\
- \text { Products become } \\
\text { competitive } \\
- \text { Products become } \\
\text { market leaders }\end{array}$ \\
\hline $\begin{array}{l}\text { 4. Program } \\
\text { objectives }\end{array}$ & 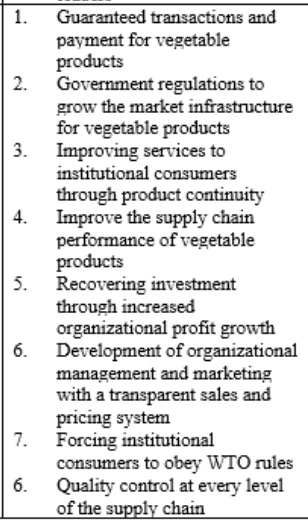 & 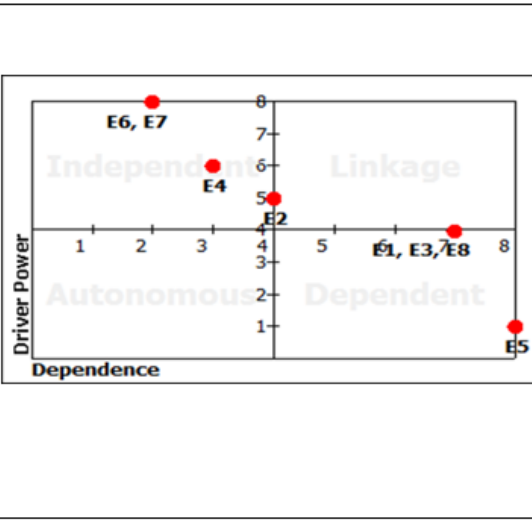 & $\begin{array}{l}\text { Level 1: } \\
\text { Level 2: } \\
\text { Level 3: } \\
\text { Level 4: } \\
\text { Level 5: }\end{array}$ & 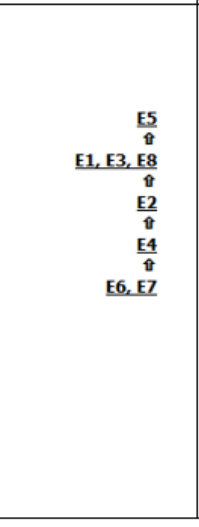 & $\begin{array}{l}\text { Development of } \\
\text { organizational } \\
\text { and marketing } \\
\text { management } \\
\text { with transparent } \\
\text { sales and pricing } \\
\text { systems } \\
\text { Forcing } \\
\text { institutional } \\
\text { consumers to } \\
\text { obey WTO rules } \\
\text { Improve the } \\
\text { supply chain } \\
\text { performance of } \\
\text { vegetable } \\
\text { products } \\
\text { Government } \\
\text { regulations to } \\
\text { grow the market } \\
\text { inffrastructure for } \\
\text { vegetable } \\
\text { products }\end{array}$ \\
\hline $\begin{array}{l}\text { 5.Institution } \\
\text { related }\end{array}$ & \begin{tabular}{|l} 
1. Hotel Association \\
2. Supplier \\
3. Central and local government \\
4. Vegetable Farmers Association \\
5. Non-Governmental \\
Organizations \\
6. Local collector traders \\
7. Transportation businessman \\
8. Microfinance institutions \\
1. Vegetable production facility \\
provider
\end{tabular} & 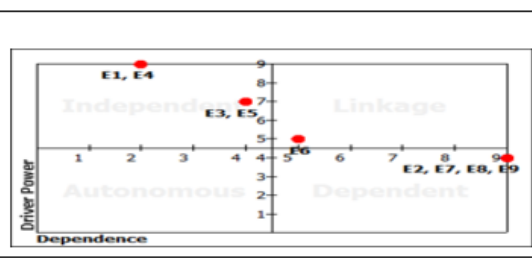 & $\begin{array}{l}\text { Level 1: } \\
\text { Level 2: } \\
\text { Level 3: } \\
\text { Level 4: }\end{array}$ & \begin{tabular}{r|}
$E 2, E 7, E 8, E 9$ \\
$\hat{E}$ \\
$\frac{E 6}{4}$ \\
$\underline{E}, E 5$ \\
$\hat{E}$ \\
$\underline{E 1, E 4}$
\end{tabular} & $\begin{array}{|ll|}- & \text { Hotel } \\
\text { - associations } \\
\text { Vegetable } \\
\text { Farmers } \\
\text { Association } \\
\text { - Central and } \\
\text { local } \\
\text { government }\end{array}$ \\
\hline
\end{tabular}

On checking the fulfillment of the Reachability Matrix transitivity rules for each element, it is observed that 
the matrix is in accordance with transitively closed rules. If it is not appropriate, the Reachability Matrix needs to be corrected for its transitivity and a modification to the SSIM. The SSIM modification is sent to the experts to be observed. After the experts agreed, the SSIM and the Reachability Matrix Revision were ready for further processing. The sub-level level is determined by the partition level in the Reachability Matrix. The resulting digraph is the basis for drawing Interpretive Structural Modeling (ISM). Driver Power-Dependence Matrix and Digraph for planning a program to strengthen the group of vegetable growers as in Table 1 columns 3 and 4 . The main sub-elements of the system drive for all elements are presented in Table 1 column 5 . The hierarchy between the sub-elements of each program planning element is shown in the column level on the chart (read from the lowest level to the highest level). When identifying the main sub-elements driving the system and the hierarchy between sub-elements, cycles and feedback on the graph can indeed be a problem. However, this difficulty has been overcome by Warfield (1971, 1972, 1973c, 1973d, and 1974) by determining the position of sub elements based on driver power, dependence, and ranking.

Driver Power-Dependence Matrices are prepared with consideration of the existence of power drivers and dependencies in each sub-element. Sub elements are classified into ADLI sectors for the elements considered. Some sub-elements might be on the dividing line of these sectors. Experts need to use expert judgment to classify the sub-elements in one sector by considering various other factors.

The ISM analysis results revealed that the program requirements of E2, E4, and E6 (see Table 1 column 3, row 1, Independent sector box) are independent variables with strong and weak dependent power drivers. This variable is important because its existence influences the needs of other programs which are categorized as dependent variables, namely sub elements: E1, E3, and E5 (Table 1 column 3, row 2, dependent sector box). interpret as linkage and autonomous variables.

The program constraints E1, E4, E3, E5 and E6 (see Table 1 column 3, row 2, Independent sector box) are independent variables with strong and weak dependent power drivers. This variable is important because its existence contributes to other program constraints that are categorized as dependent variables, namely subelements: E2, E7, E8, E9, and E10 (Table 1 column 3, row 2, dependent sector box). Also not found are the subelements of the program objectives classified as linkage and autonomous variables.

Possible changes E1, E3, E4, E5 and E12 (see Table 1 column 3, row 3, Independent sector box) are independent variables with strong and weak dependent power drivers. This variable is important because its existence provides other changes that are categorized as dependent variables, namely sub elements: E2, E6, E7, E8, E9, E10, and E11 (Table 1 column 3, row 3, dependent sector box). Possible substitution changes that are classified as linkage and autonomous variables are missing.

The program objectives E6, E7, E4, and E2 (see Table 1 column 3, row 4, Independent sector box) are independent variables with strong and weak dependent power drivers. This variable is important because its existence assists other program objectives which are categorized as dependent variables, namely sub-elements: E1, E3, E8, and E5 (Table 1 column 3, row 3, dependent sector box). The sub-program objectives that are classified as linkage and autonomous variables are missing.

Related institutions E1, E4, E3, and E5 (see Table 1 column 3, row 1, Independent sector box) are independent variables with strong and weak dependent power drivers (also known as leading indicators). This variable is important because its existence assists other related which are categorized as dependent variables (also called lagging indicators), namely sub elements: E6, E2, E7, E8, and E9 (Table 1 column 3, row 1, dependent sector box). There are no sub elements of program objectives that are classified as linkage and autonomous variables.

The ISM studied in relation to program planning is a significant progress in systems analysis. The methodology that results in the ranking of driver-power sub-elements of the Reachability Matrix is an improvement in the study of the sub-element hierarchy and maintains the superiority of binary and directed graph theory. The methodology of variable classification with ISM is a technique of identifying the types of roles of each variable in a program and presenting a clear graphical visualization of the structure and relationships of variables in the program while appreciating the complexity of program planning and the evolution of policies and strategies. Synthesis of the Main Sub element Driving the System

The results of the ISM analysis produced the main sub-elements driving the system in each element of the program planning for strengthening the group of vegetable farmers and used as information material and starting point in formulating or synthesizing the criteria in making a model for strengthening the group of plateau vegetable farmers. The main sub-system driver selected from each element of the system of strengthening the vegetable farmer group has a role as an independent variable or has the power as a driver for the system (see Table 1, column 5). It can also be interpreted that this sub-element is a priority demand which must first be fulfilled before the other subelements.

Starting from the main system driving sub-elements, the experts then synthesized the main system driving sub-elements and produced a multi-criteria development model for strengthening the group of plateau vegetable farmers. Special attention to these criteria can increase the effectiveness of the system because it is a chain of functional relationships between statements of program needs with specific statements of problems that need to be 
solved. In formulating the multi-criteria of developing a model for strengthening the group of vegetable farmers, the experts carefully examined the main sub-elements of the system drive according to the institutions involved, the constraints, and the objectives of the program. In the synthesis process to produce multi criteria for the formation of a strengthening model group of vegetable farmers, it is possible to add and subtract the main subelements of the system drive that are identified. Multi-criteria formulation in building a model of strengthening the group of vegetable farmers as in Table 3.

Table 3. Synthesis of Main Elements of a System Mover to Generate Multi Criteria Model for Strengthening Vegetable Farmer Groups

\begin{tabular}{|c|c|}
\hline No. & Criteria \\
\hline 1. & $\begin{array}{l}\text { Organizational engineering and marketing strategies in the context of achieving the objectives of } \\
\text { marketing plateau vegetables }\end{array}$ \\
\hline 2. & $\begin{array}{l}\text { Increased institutional consumer market access in an effort to gain market share and broader market } \\
\text { segments supported by government regulations related to the plateau vegetable market infrastructure }\end{array}$ \\
\hline 3. & $\begin{array}{l}\text { Logistics consolidation and packing storage as well as quality inspection and HR marketing for } \\
\text { vegetables }\end{array}$ \\
\hline 4. & $\begin{array}{l}\text { Improved the performance of a comprehensive supply chain that utilizes ICT to balance demand and } \\
\text { supply while guaranteeing vegetable transactions and payments }\end{array}$ \\
\hline
\end{tabular}
A Model of Strengthening Vegetable Farmers Group (Temperated Vegetables) to Meet the Tourism Sector Market in Bali

The model of strengthening the plateau vegetable farmer group that was developed has considered the need to strengthen the vegetable farmer group using an appreciative inquiry method, through: (a) rapid research, commensurate with the RRA (Rapid Rural Appraisal) method which involves a multidisciplinary team in collecting and analyzing data causally logical; (b) in-depth interviews and direct observation; (c) participatory workshops, commensurate with the Sigma-5-based IM (Interactive Management) method (facilitator, demosophia / situation room, computer, consensus methodology, and participant groups) and the results documented; (d) peer review which is carried out twice, namely during the discussion of rapid research and workshops.

The model of strengthening the plateau vegetable farmer group is visualized as vegetable supply chain management in the context of business change and organizational transformation. The plateau vegetable farmer group is transformed into a socio-business institution (social enterprise is a business that is driven by a cause whose main reason for existence is to increase social goals and serve the common good), namely Village-owned business entity. Plateau Village-owned business entity is interpreted as The Channel Master. Village-owned business entity as The Channel Master (also called Focus Company) is a socio-agro-enterprise institution that embraces inclusive all groups of plateau vegetable farmers. The plateau vegetable Village-owned business entity are the main players in the plateau vegetable business operating in Bali. Figure 1 illustrates the plateau vegetable supply chain used as a case study. The product flow in vegetable supply chain management follows a series of internal plateau vegetable business processes.

In running its business, Village-owned business entity plateau vegetables carry out a vertical integration strategy that has a vegetable plantation and a packing house. However, the demands of the institutional consumer market demand exceeds their capacity so that a vertical coordination strategy is implemented with partner Villageowned business entity, including the procurement strategy of ready-to-sell vegetables from the open market originating from partner Village-owned business entity or other vegetable farmer groups.

The implementation of these three strategies causes the supply chain network to be formed into multiple levels and complex. Figure 1 reveals that the Village-owned business entity of plateau vegetables get a regular flow of vegetables every day from their own gardens and partner Village-owned business entity gardens. Villageowned business entity buys vegetables from the open market when there is a gap between market demand and the availability of vegetables from its own garden. The results of purchases from the open market are sent directly to the plateau vegetable Village-owned business entity which are also the center of vegetable distribution. Furthermore, ready-to-sell vegetable products are sent to consumer institutions in Bali.

Village-owned business entity, which becomes The Channel Master, is divided into three divisions, namely the Vegetable Garden Division, the Processing House Division, and the Distribution Center Division. In the Village-owned business entity internal business there is a flow of products (fresh vegetables) and management decisions that connect the divisions mentioned above. Management decisions in the form of managing the flow of information needed to control the flow of products through effective and efficient internal business processes.

Business transactions between the plateau vegetable Village-owned business entity and institutional consumers in the form of vegetable product flow, order flow and product specifications, and payment flow. Consumer consumers (buyers) submit orders and specifications of desired vegetable products and provide payment rewards if their requests are fulfilled.

Plateau Village-owned business entity manages the delivery of order and specification streams and payments to vegetable gardens under the management of Village-owned business entity / The Channel Master. Orders and 
specifications of vegetable products from institutional consumers are met from Mita Village-owned business entity, if demand cannot be fulfilled from the vegetable garden itself. Village-owned business entity masters deliver orders and specifications as well as payments to coordinated Village-owned business entity partners. Partner Villageowned business entity, fulfill orders and specifications specified by the buyer.

Vegetable supply from the garden itself is harvested, washed, grading, and finally packaged into ready-tosell products according to the SOP of the Village-owned business entity processing division. Next, deliveries to packing houses, cold storages and distribution to markets are in line with the SOP of the distribution center division. Based on intra and inter partnership interaction with Village-owned business entity in partnership, it is explicitly illustrated that there is a loop of feedback (feedback loops) in vegetable supply chain management. Institutional consumers become drivers for Village-owned business entity and its business partners. Any changes in orders and specifications in the form of demands for quality, quantity, delivery time, price and continuity need to be responded to by all stakeholders involved in the plateau vegetable supply chain in Bali.

\section{Conclusion}

An important element for the establishment of a model for strengthening groups of plateau vegetable farmers is the related institutions, constraints, and program objectives. The main sub-elements driving the system in (a) elements of related institutions are the hotel association, as well as the vegetable farmers association, and the central and regional governments; (b) elements of the program constraints are the market access of low-income vegetable farmers groups, the performance of the plateau vegetable supply chain is not optimal, the management of the organization is weak, and the marketing system and prices are not transparent; (c) program objective elements are government regulations to grow the market infrastructure of vegetable products, improve the performance of vegetable product supply chains, develop organizational management and marketing with a transparent sales and pricing system, and force institutional consumers to comply with WTO rules. Synthesis of various main sub-elements driving the system to produce criteria for developing models for strengthening groups of upland vegetable farmers is organizational engineering and marketing strategy in the context of achieving marketing objectives of plateau vegetables, increasing market access for institutional consumers in an effort to gain market share and wider market segments supported government regulations related to plateau vegetable market infrastructure, consolidation of logistics and packing storage as well as quality inspection and human resource marketing of vegetables, improving the performance of a comprehensive supply chain that utilizes ICT to balance demand and supply while guaranteeing vegetable transactions and payments. The diagrammatic model of strengthening tempered vegetables farmers group oriented towards developing organizational management and strategic marketing, and supported by government regulations in growing market infrastructure ensures an increase in vegetable supply chain performance and tourism market access.

\section{VI.Recommendations}

1. Application of an effective model to strengthen the plateau vegetable farmers group requires a multisectoral synergy to support innovative strengthening and funding programs, mainly in terms of: (a) increasing productive area and protection system of vegetable gardens under the coordination of Village-owned business entity. Its activities include the development of a variety of vegetable areas, activating field schools (SL), specifically SL-GAP (Good Agricultural Practices), SL-PHT (Integrated Pest Control), and SL-DPI (Impact of Climate Change), registration of LU (business land), product certification; (b) facilitation of processing and marketing ready-to-sell products, updating postharvest equipment, packing houses, activation of SLGHP (Good Handling Practices), packing house registration, yield processing equipment, strengthening marketing of plateau vegetable Village-owned business entity, including management and marketing of ICTbased products to achieve marketing targets, supported by management and technical from relevant government agencies.

2. The aim of improving the performance of the supply chain of vegetable products has the consequence of the creation of an organized market infrastructure while realizing a strong market position with a transparent pricing and sales system. Strengthening supply chain performance can balance the supply-demand of vegetable products, improve the bargaining position of the vegetable farmer organization, and in turn obtain better profit margins for all stakeholders involved. Realizing these objectives requires full planning and programs, including outlining critical success factors, a roadmap and a comprehensive plan of action.

3. Problems in the management of the plateau vegetable supply chain are complex and there are still phenomena that have not been raised to the problem in this study so that efforts are needed to expand the scope of the proposed model to answer and overcome the problems of other phenomena, including: sustainable vegetable agribusiness development (sustainable vegetables ), the development of export markets, and the development of downstream industries in the domestic market that are able to increase the added value of products, the profits of domestic vegetable and foreign exchange businesses for the country. Institutional consumer satisfaction becomes the main objective of Village-owned business entity. Therefore, research on the 
characteristics and values of consumer satisfaction of institutions visualized in the form of house of quality and measurement of the performance of a comprehensive supply chain system of vegetable products needs to be done. It is necessary to establish an HR management engineering model involved in the vegetable supply chain. Thus, it is hoped that a precise HR productivity development strategy in the design of farmer organization and plateau vegetable supply chain management can be obtained.

\section{Acknowledgements}

Thank you to the Chancellor of Udayana University, the Provincial Government of Bali, the Bali Sustainable Development Foundation, the Tri Hita Karana Society and the Tri Hita Karana Foundation for facilities and funding support for the smooth running of this research.

\section{References}

Darmawan D P. 2017. Pengambilan Keputusan Terstruktur Dengan Interpretive Structural Modeling. Elmatera: Yogyakarta.

Eriyatno. 2003. Ilmu Sistem: Meningkatkan Mutu dan Efektivitas Manajemen. IPB Press: Bogor.

Evans, J.R. and Berman, B. 1997. Marketing. $7^{\text {th }}$ end. Prentice Hall, Upper Saddle River, NJ 074558.

Godet M. 1985. Scenarios and Strategic Management. Economic Press. Paris, pp. 4445.

Hasan A, Sarkis J and Shankar R. 2007. Evaluating Environment-Conscious Manufacturing Barriers with Interpretive Structural Modelling. CRC Press. Delhi, pp. 509-524.

Natawidjaja, R.S. 2005.Modern Market Growth and the Changing Map of the Retail Food Sector in Indonesia. Presented at Pacific Food System Outlook (PFSO) $9^{\text {th }}$ Annual Forecasters Meeting. May 10-13, 2005. in Kunming, China. The Pacific Food System Outlook 2005

Parining, N. 1999. The Extent to Which the Balinese Vegetable Farmers Are Able to Meet the Demands of Local Tourist hotels for Fresh Vegetables. Muresk Institute of Agriculture, Curtin University of Technology, Australia.

Ravi V and Shankar R. 2005. Analysis of Interactions among the Barriers of Reverse Logistics, Technological Forecasting and Social Change. vol. 72, pp. 1011-1029.

Saxena J P, Vrat, P, and Sushil. 1990. Linkages of Key Elements in Fuzzy Program Planning. Systems Research, vol. 7 no.3, pp.147-158.

Saxena J P, Sushil and Vrat P. 1992. Hierarchy and Classification of Program Plan Elements Using Interpretive Structural Modeling: A Case Studi of Energy Conservation in the Indian Cement Industry. System Practice, vol. 5 no. 6, pp.651-670.

Shahabadkar P, Hebbal SS and Prashant S. 2012. Deployment of Interpretive Structural Modelling Methodology in Supply Chain Management-an Overview. International Journal of Industrial Engineering \& Production Research, vol. 23 no. 3, pp. 195-205.

Tanziha, Ikeu. 2011. Model Pemberdayaan Petani Menuju Ketahanan Pangan Keluarga. Journal of Nutrition andFood

Warfield J N. 1971. The DELTA Chart-a Method for R\&D Project Portrayal. IEEE Transactions on Engineering Management, pp. 132-139 (Correction, May 1972, p. 74).

Warfield J N. 1972. Intent structures, IEEE Transactions on Systems, Men and Cybernetics. vol. 3 no. 2, pp. 133140

Warfield J N. 1973c. On Arranging Elements of Hierarchy in Graphical Form. IEEE Transactions on Systems, Men and Cybernetics, vol. 3 no. 2, pp. 121-132.

Warfield J N. 1973d. An Assault on Complexity. Battelle Monograph, 3, Battelle Memorial Institute, Columbus, Ohio.

Warfield J N. 1974. Developing Interconnected Matrices in Structural Modelling. IEEE Transactions on Systems, Men and Cybernetics, vol. 4 no. 1, pp. 51-81.

Warfield J N and Cardenas, A R. 1994. A Handbook of Interactive Management. Iowa State University Pres: Ames. Warfield J N. 2006. An Introduction to Systems Sciences. World Scientifi: Singapore.

World Bank 2007 Agriculture for Development. World Development Report, 2008. Washington, DC: World Bank. 